\title{
Geospatial Analysis in African Archaeology: Current Theories, Topics, and Methods
}

\author{
Carla Klehm • Cameron Gokee
}

Published online: 28 February 2020

(C) Springer Science+Business Media, LLC, part of Springer Nature 2020

The study of social space has become a central concern of African archaeology over the past three decades. Responding to critiques of the search for grand narratives (Stahl 1999), many scholars have turned their attention to more synchronic interpretations of social complexity and subjective experience in specific times and places - a move that encourages more critical analyses of socio-spatial relations within sites and across landscapes. In this way, an explicit concern with space aligns with calls for greater theory building in African archaeology (Wynne-Jones and Fleisher 2015) as we pose new questions, and revisit old ones, concerning human-environment interactions (e.g., Chami et al. 2001; McIntosh 2005), power and authority (e.g., Holl 2006; Monroe 2014; Richard 2018; Sinclair 1987), ritual and cosmology (e.g., Insoll et al. 2013), colonial entanglements and historical processes (e.g., Crossland 2014; González-Ruibal 2014; MacEachern 2018; Monroe and Ogundiran 2012), and archaeology and heritage (Schmidt and Pikirayi 2016).

C. Klehm

Center for Advanced Spatial Technologies, University of Arkansas, Fayetteville, AR, USA

C. Klehm $(\bowtie)$

Department of Anthropology, University of Arkansas, Fayetteville, AR, USA

e-mail: cklehm@gmail.com

C. Gokee

Department of Anthropology, Appalachian State University, Boone, NC, USA
Answering these questions about the social production of space ultimately depends on our methods for collecting regional and site-scale data. Spatial approaches have a deep history in archaeology where researchers have long been concerned with the location and measurement of artifacts, sites, and cultural and natural features, as well as the relations between them (e.g., Adams 1965; Clarke 1977; Hodder and Orton 1976; Phillips and Willey 1953; Willey 1953). In Africa, studies dating back to the 1960s have explored humanenvironmental relationships and settlement patterns with aerial photographs (e.g., Denbow 1979; Maggs 1976; Mason 1968; Seddon 1968) and, on a finer scale, with hand-drawn maps detailing site structure, artifact densities, and mobility (Binford 1980; Clark 1971; Collett 1979; Sampson 1984). Some of these early studies employ statistical analyses of spatial relationships (e.g. Sinclair 1987). With recent innovations in geospatial methods for collecting and analyzing archaeological data, we argue that African archaeology is increasingly well-equipped to make new discoveries and address fundamental questions about past societies and cultures and in turn drive methodological innovations.

Around the world, geospatial technologies are becoming an integral part of archaeological data collection and analysis. Geographic information systems (GIS) software and remote sensing (RS) technologies have advanced rapidly, and software and satellite imagery have become increasingly affordable and widely available (Kvamme 1999; Lasaponara and Masini 2012; Opitz and Herrmann 2018). Software and data 
processing capacities are addressing complex questions in three dimensions (Merlo 2016) and with large datasets, some of which are continent-wide or span thousand-year timescales (Cooper and Green 2016). Archaeological survey strategies using GPS and GNSS are becoming the norm, so features and artifact data can be quickly digitized and analyzed in geospatial databases (Hill et al. 2019). Near-surface geophysics is improving our ability to noninvasively target features for excavation and even detect site layout (Witten 2006). Airborne remote sensing has expanded beyond earlier aerial photography to include space-borne platforms with high-resolution imagery (Comer and Harrower 2013; De Laet et al. 2007; Lasaponara and Masini 2012; Parcak 2009). Black-and-white photography, first enhanced by color, has now been replaced by multispectral and hyperspectral imagery including data from both visible and non-visible wavelengths (e.g., near, middle, and thermal infrared, UV) (Abrams and Comer 2013; Dumitru and Harrower 2018a; Dumitru and Harrower 2018b). SAR (Synthetic Aperture Radar) and LiDAR (Light Detection and Ranging) help detect natural and archaeological landscapes and thereby overcome major impediments such as vegetation cover (Chen et al. 2017; Opitz and Cowley 2013; Parcak 2017). These techniques and satellite imagery platforms are helping archaeologists better understand the environmental contexts in which past peoples lived by locating sites and analyzing their structure with respect to various natural and cultural features. Geospatial methods can even be used to predict site locations and monitor cultural heritage in regions with political conflict. The increasing number of publications on geospatial applications in archaeology - of which this special issue is onedemonstrates how GIS and remote sensing have matured from emerging specialties to ones seen as integral, if not essential, to archaeological practice.

Geospatial technologies are transforming African archaeology, especially because of the diversity of contexts in which research takes place. Recent synthesis articles by Magnavita (2016) and Davis and Douglass (this issue) demonstrate that geospatial and remote sensing applications are growing, despite a long list of challenges that Africanists face: vast and difficult-toaccess terrain, environmental challenges, inadequate infrastructure, political instability, local bureaucratic challenges, and the prohibitive costs of conducting largescale surveys or obtaining aerial photographs and satellite imagery, among others. And yet, Africanists have excelled in the creative application of geospatial technologies. From GIS (Osei 2014) to geophysics (Fitton and Wynne-Jones 2017; Klehm and Ernenwein 2016; Magnavita 2017; Wynne-Jones 2012) to UAV systems (Bergstrom et al. 2019), Africanists have actively collected remote sensing data where they were previously unavailable. The availability, affordability, and reliability of imagery such as Landsat, ASTER, SRTM, and Google Earth showcase how widely available imagery can be used effectively across multiple scales and geographic contexts (e.g., Bubenzer et al. 2018; Harrower and D'Andrea 2014; Khalaf and Insoll 2019; Sadr and Rodier 2012; Sampson et al. 2015). Case studies that use high-resolution satellite imagery (Biagetti et al. 2017; Parcak et al. 2016; Reid 2016), hyperspectral imagery (Thabeng et al. 2019a), and LiDAR imagery (Sadr 2016) have further improved our ability to assess anthropogenic landscapes at increasingly finer scales. Applications range from classifying natural and anthropogenic landscapes (Schmid et al. 2008; Thabeng et al., this issue) to building predictive models (Davis et al. 2020; Klehm et al. 2019; Thabeng et al. 2019b) and further include monitoring vulnerable cultural heritage (Elfadaly et al. 2018; Parcak 2017; Parcak et al. 2016; Rayne et al. 2017; see also the EAMENA Project [https://eamena.arch.ox.ac.uk/]).

The papers in this special issue, emerging from a session at the Society for American Archaeology conference in Washington, D.C., in 2018, further explore the interplay between African archaeology and geospatial methods from three broad perspectives. First, several contributors examine the technical possibilities and limits of using satellite imagery to detect archaeological sites and model their physical environs. Beginning with a survey of recent aerial and satellite remote sensing applications in Africa, Dylan Davis and Kristina Douglass compare how direct and indirect approaches can help us to document sites faster, and over larger areas, than more traditional methods of survey. Direct approaches are a powerful means to identify sites using high-resolution satellite imagery and complex computational methods (see Thabeng et al., this issue), but the imagery costs and technical proficiency required by these approaches put them out of reach for many archaeologists. Indirect approaches predict site locations using lower resolution satellite imagery and software tools, such as GIS and Google Earth Engine (see Arthur et al., Pawlowicz et al., this issue), more readily accessible to archaeologists. Davis and Douglass call for 
better integration of these approaches into archaeological survey projects across Africa, and particularly in coastal areas, where climate change and anthropogenic activity are growing threats to archaeological sites.

Focusing on direct approaches to site identification in Southern Africa, Olaotse Thabeng, Stefania Merlo, and Elhadi Adam evaluate the prediction accuracies for six common multispectral sensors (GeoEye, Landsat 8 OLI, RapidEye, Sentinel-2, SPOT 5, and WorldView-2). This study begins with the collection of hyperspectral field data to map the spectral signatures for archaeological sites (midden, vitrified dung, non-vitrified dung) and a control sample of non-site locales. These signatures, resampled to the bands of different sensors, then provide the training and test data for two site classification algorithms. Importantly, the authors show that the spectral resolutions of freely available imagery (e.g., Landsat 8 OLI, Sentinel-2) are well suited for identifying archaeological sites in Southern Africa, though in-field spectroscopy will be essential for building libraries of the spectral signatures associated with sites in other regions.

Michael Harrower and colleagues showcase how satellite remote sensing can be used to test hypotheses about the relationships between archaeological sites and their physical landscapes - specifically, access to water for cultivation. First, the classification of landforms from multispectral imagery and digital elevation models made possible their stratified random survey to record sites across a study area centered on the Pre-Aksumite center of Yeha in the Ethiopian highlands. The authors then use a suite of GIS tools to assess these site locations against satellite-derived models of soil wetness and evapotranspiration. Surprisingly, this analysis reveals no correlation between prehistoric settlement patterns and water resources; this suggests that rainfed agriculture and terraces, rather than large-scale irrigation projects, have long been sufficient for sustaining complex societies in the region.

With this interpretation of Pre-Aksumite landscape use, Harrower and colleagues also introduce a second perspective adopted by other papers in this special issue: the integration of new geospatial data and methods into site- and landscape-scale analyses to better address questions about social organization and subjective experience in African pasts. Well-known questions of Bantu Expansion, for example, find a new focus in research by Matthew Pawlowicz, Jeffrey Fleisher, and Kathryn de Luna on human agency and movement in the Basanga region of Zambia. Drawing on the results of an expansive shovel-test survey, these authors use GIS interpolation tools to map land-use patterns and mobility around a series of Iron Age settlement mounds representing rootedness in the landscape. These regional data, along with multispectral satellite imagery, also form the basis for a predictive model to explain rootedness in terms of landscape factors such as elevation and proximity to water and cultivable land. Despite mixed results when using site reconnaissance and UAV imagery to test this model, the endeavor shows how geospatial methods can be critical for applying novel theoretical approaches to long-standing archaeological questions.

Along these same lines, Cameron Gokee and Ibrahima Thiaw examine the political ecology of precolonial states and villages along the Falemme River in Eastern Senegal. Here the integration of data from two archaeological surveys in GIS enables a comparison of agropastoral settlement dynamics across a broad region encompassing political centers and their peripheries. Asking how these dynamics impacted village life, the authors use multispectral satellite imagery to refine models of the physical environment, including topography, water, and soils, central to the everyday experiences and politics of people occupying past settlement sites. The results add nuance to state-centered histories of the region by emphasizing that village communities were everywhere grounded in local concerns about land, even as they responded to the geopolitics of statecraft and trade.

Adopting a much different approach to the social production of space, Monika Baumanova explores the sensory experience of urban centers in the Sahel and along the Swahili coast. Specifically, she employs space syntax analysis to interpret how the built environment would have simultaneously shaped visual and kinesthetic perception at multiple scales - from houses to streets to residential quarters. Notably, this study looks beyond questions of social process to consider past subjective experiences, while also demonstrating the insights to be gleaned by applying new spatial methods to African urban layouts that have been previously published or are openly available on web platforms such as Google Earth Engine.

A final perspective in this special issue considers the interplay between geospatial technologies and community archaeology in Africa. Whereas local knowledge and labor are always vital for documenting sites and landscapes (see Harrower et al., Pawlowicz et al., this 
issue), the paper by Kathryn Arthur, Sean Stretton, and Matthew Curtis demonstrates how mapmaking can and should be a locus for more even collaborations with descendant communities. Working with Boreda elders in Southern Ethiopia, these authors set out to record the architectural features, physical settings, and oral histories associated with a series of sacred groves tracing the Boreda settlement history in the region. On one level, the remains of defensive structures and GIS viewshed analyses suggest that these sites were defensive, corresponding to histories of conflict and resistance to slave raiders. On another level, the process of participatory heritage mapping and the use of open-access tools like Google Earth Engine enable the Boreda to be leading partners in writing (and charting) their past.

This brings up broader issues about the ethics of access to geospatial technologies in Africa where doing archaeology "from space" risks moving away from "on the ground" collaborations with local communities. Limited access to training, equipment, and software associated with geospatial technologies also requires us to reflect upon who acts as the producers of knowledge, whose stories are being represented, and who has access to archived materials. Authors in this issue (e.g., Arthur et al.) and beyond (Khalaf and Insoll 2019) demonstrate the potential for open-access imagery in a variety of archaeological applications; Davis and Douglass (this issue) also provide a table of open-source data repositories and software platforms to access. While neither straightforward nor often easy, we call for geospatial research in African archaeology to establish best practices for outreach, collaboration, and training opportunities with African institutions and local communities, as well as for the archiving and publication of digital data.

Recognizing that GIS and RS supersede traditional divisions in African archaeology, such as different periods, geographic regions, and theoretical orientations, the papers in this special issue aim to be widely applicable. Arranged by methodological emphasis, the case studies move from technical discussions of specific geospatial tools to general applications for addressing specific sociohistorical topics. Each paper clearly explains the links between their archaeological questions and analytical methods, as well as how their results advance our understanding of African pasts and heritage resources. Several of the papers can serve as learning models for archaeologists who are new to GIS or curious about its applications to their work. Others represent recent advances in geospatial applications of greater interest to more seasoned GIS practitioners, demonstrating the potential for African scholarship to contribute to methodological innovations.

We would like to end by noting that the current set of papers does not represent the whole range of geospatial techniques being used in African archaeology. In particular, geophysics and 3D digital imaging and visualization methods are regrettably unrepresented. If these are of interest, we would direct the readers to the following representative selection conducted by archaeological and paleoanthropological colleagues (e.g., for photogrammetry and 3D modeling, see https://www. zamaniproject.org/; Armstrong et al. 2018; Bleed et al. 2017; Heimlich 2017; Kruger et al. 2016; Rüther and Rajan 2007; Rüther et al. 2019. For geophysics, see Magnavita 2016 for overview; Fitton and WynneJones 2017; Fleisher and Sulas 2015; Klehm and Ernenwein 2016; Lanzarone et al. 2019; S. Magnavita 2017; Olorunfemi et al. 2019; Welham et al. 2014).

Nevertheless, this special issue is a contribution to how new geospatial technologies are opening avenues for more empirical analyses and nuanced interpretations among African archaeologists.

\section{References}

Abrams, M., \& Comer, D. (2013). Multispectral and hyperspectral technology and archaeological applications. In D. Comer \& M. Harrower (Eds.), Mapping archaeological landscapes from space (pp. 57-71). SpringerBriefs in Archaeology (Vol. 5). New York: Springer. https://doi.org/10.1007/978-14614-6074-9_6.

Adams, R. M. C. (1965). Land behind Baghdad: A history of settlement on the Diyala Plains. Chicago: University of Chicago Press.

Armstrong, B. J., Blackwood, A. F., Penzo-Kajewski, P., Menter, C. G., \& Herries, A. I. R. (2018). Terrestrial laser scanning and photogrammetry techniques for documenting fossilbearing palaeokarst with an example from the Drimolen Palaeocave System, South Africa. Archaeological Prospection, 25, 45-58.

Bergstrom, K., Lawrence, A. B., Pelissero, A. J., Hammond, L. J., Maro, E., Bunn, H. T., \& Musiba, C. M. (2019). Highresolution UAV map reveals erosional patterns and changing topography at Isimila, Tanzania. South African Journal of Science, 115(7/8). https://doi.org/10.17159/sajs.2019/5911.

Biagetti, S., Merlo, S., Elhadi, A., Lobo, A., Conesa, F., Knight, J., et al. (2017). High and medium resolution satellite imagery to evaluate Late Holocene human-environment interactions in arid lands: A case study from the Central Sahara. Remote Sensing, 9(4), 351. https://doi.org/10.3390/rs9040351. 
Binford, L. R. (1980). Willow smoke and dogs' tails: Huntergatherer settlement systems and archaeological site formation. American Antiquity, 45(1), 4-20.

Bleed, P., Douglass, M., Sumner, A., Behrendt, M., \& Mackay, A. (2017). Photogrammetrical assessment of procedural patterns and sequential structure in "handaxe" manufacture: A case study along the Doring River of South Africa. Lithic Technology, 42(1), 3-12.

Bubenzer, O., Bolten, A., \& Riemer, H. (2018). In search of the optimal path to cross the desert: Geoarchaeology traces old trans-Saharan routes. In C. Siart, M. Forbriger, \& O. Bubenzer (Eds.), Digital Geoarchaeology. Natural science in archaeology. New York: Springer. https://doi.org/10.1007 1978-3-319-25316-9_9.

Chami, F. A., Pwiti, G., \& Radimilahy, C. (Eds.). (2001). People, contact and the environment in the African past. Dar es Salaam: Dar es Salaam University Press.

Chen, F., Lasaponara, R., \& Masini, N. (2017). An overview of satellite Synthetic Aperture Radar remote sensing in archaeology: From site detection to monitoring. Journal of Cultural Heritage, 23(supplement), 5-11.

Clark, J. D. (1971). Human behavioral differences in Southern Africa during the Later Pleistocene. American Anthropologist, 73, 1211-1236.

Clarke, D. L. (Ed.). (1977). Spatial archaeology. London: Academic Press.

Collett, D. P. (1979). The archaeology of the stone walled settlements in the Eastern Transvaal, South Africa. Johannesburg: $\mathrm{PhD}$ dissertation, University of Witwatersrand.

Comer, D. C., \& Harrower, M. J. (2013). Mapping archaeological landscapes from space. New York: Springer-Verlag.

Cooper, A., \& Green, C. (2016). Embracing the complexities of 'big data' in archaeology: The case of the English landscape and identities project. Journal Archaeological Method and Theory, 23, 271-304.

Crossland, Z. (2014). Encounters with ancestors in highland Madagascar: Material signs and traces of the dead. Cambridge: Cambridge University Press.

Davis, D., Andriankaja, V., Carnat, T. L., Chrisostome, Z. M., Colombe, C., Fenomanana, F., et al. (2020). Satellite-based remote sensing rapidly reveals extensive record of Holocene coastal settlement on Madagascar. Journal of Archaeological Science, 115, 105097. https://doi.org/10.1016/j. jas.2020.105097.

De Laet, V., Paulissen, E., \& Waelkins, M. (2007). Methods for the extraction of archaeological features from very highresolution Ikonos-2 remote sensing imagery, Hisar (Southwest Turkey). Journal of Archaeological Science, 34(5), 830-841.

Denbow, J. R. (1979). Cenchrus ciliary: An ecological indicator of Iron Age middens using aerial photography in eastern Botswana. South African Journal of Science, 75(9), 405.

Dumitru, I., \& Harrower, M. J. (2018a). Mapping ancient production and trade of copper from Oman and obsidian from Ethiopia. In A. Manzo, C. Zazzaro, \& D. J. De Falco (Eds.), Stories of globalization: The Red Sea and the Persian Gulf from Late Prehistory to Early Modernity (pp. 74-94). Leiden: Brill.

Dumitru, I., \& Harrower, M. J. (2018b). From rural collectibles to global commodities: Copper from Oman and obsidian from Ethiopia. In N. Boivin \& M. Frachetti (Eds.), Globalization in prehistory: Contact, exchange and the people without history' (pp. 232-262). Cambridge: Cambridge University Press.

Elfadaly, A., Attia, W., \& Lasaponara, R. (2018). Monitoring the environmental risks around Medinet Habu and Ramesseum Temple at West Luxor, Egypt, using remote sensing and GIS techniques. Journal of Archaeological Method and Theory, 25(2), 587-610.

Fitton, T., \& Wynne-Jones, S. (2017). Understanding the layout of early coastal settlement at Unguja Ukuu, Zanzibar. Antiquity, 91(359), 1268-1284.

Fleisher, J., \& Sulas, F. (2015). Deciphering public spaces in urban contexts: Geophysical survey, multi-elemental soil analysis, and artifact distributions at the 15th-16th-century AD Swahili settlement of Songo Mnara, Tanzania. Journal of Archaeological Science, 55, 55-70.

González-Ruibal, A. (2014). An archaeology of resistance: Materiality and time in an African borderland. Lanham: Rowman \& Littlefield.

Harrower, M. J., \& D'Andrea, A. C. (2014). Landscapes of state formation: Geospatial analysis of Aksumite settlement patterns (Ethiopia). African Archaeological Review, 31(3), 513541.

Heimlich, G. (2017). Documenting and studying a rock-art site: The example of the Lovo massif. In A. L. Smith, E. Cornelissen, O. Gosselain, \& S. MacEachern (Eds.), Field manual for African archaeology (pp. 142-145). Tervuren: Royal Museum for Central Africa.

Hill, A., Limp, F., Casana, J., Laugier, E., \& Williamson, M. (2019). A new era in spatial data recording: Low-cost GNSS. Advances in Archaeological Practice, 7(2), 169-177.

Hodder, I., \& Orton, C. (1976). Spatial analysis in archaeology. Cambridge: Cambridge University Press.

Holl, A. F. C. (2006). West African early towns: Archaeology of households in urban landscapes. Ann Arbor: University of Michigan Museum of Anthropology.

Insoll, T., MacLean, R., \& Kankpeyeng, B. (Eds.). (2013). Temporalising anthropology: Archaeology in the Talensi Tong Hills, northern Ghana. Frankfurt am Main: Africa Magna Verlag.

Khalaf, N., \& Insoll, T. (2019). Monitoring Islamic archaeological landscapes in Ethiopia using open source satellite imagery. Journal of Field Archaeology, 44(6), 401-419.

Klehm, C. E., \& Ernenwein, E. G. (2016). Iron Age transformations at Mmadipudi Hill, Botswana: Identifying spatial organization through electromagnetic induction survey. African Archaeological Review, 33(1), 45-59.

Klehm, C., Barnes, A., Follett, F., Simon, K., Kiahtipes, C., \& Mothulatshipi, S. (2019). Toward archaeological predictive modeling in the Bosutswe region of Botswana: Utilizing multispectral satellite imagery to conceptualize ancient landscapes. Journal of Anthropological Archaeology, 54, 68-83.

Kruger, A., Randolph-Quinney, P. S., \& Elliott, M. C. (2016). Multimodal spatial mapping and visualisation of Dinaledi Chamber and rising star cave. South African Journal of Science, 112(5-6), 1-11.

Kvamme, K. L. (1999). Recent directions and developments in geographical information systems. Journal of Archaeological Research, 7(2), 153-201.

Lanzarone, P., Seidel, M., Brandt, S., Garrison, E., \& Fisher, E. (2019). Ground-penetrating radar and electrical resistivity 
tomography reveal a deep stratigraphic sequence at Mochena Borago Rockshelter, Southwestern Ethiopia. Journal of Archaeological Science: Reports, 26, 101915.

Lasaponara, R., \& Masini, N. (Eds.). (2012). Satellite remote sensing: A new tool for archaeology. Heidelburg: SpringerVerlag.

MacEachern, S. (2018). Searching for Boko Haram: A history of violence in Central Africa. Oxford: Oxford University Press.

Maggs, T. (1976). Iron Age patterns and Sotho history on the southern Highveld: South Africa. World Archaeology, 7(3), 318-332.

Magnavita, C. (2016). Contributions of archaeological geophysics to field research in sub-Saharan Africa: Past, present, future. Azania, 51, 115-141.

Magnavita, S. (2017). First geophysical exploration in the tumuli zone of Central Senegal: A multidimensional approach. Azania, 52, 100-122.

Mason, R. J. (1968). Transvaal and Natal Iron Age settlement revealed by aerial photography and excavation. African Studies, 27(4), 167-180.

McIntosh, R. J. (2005). Ancient Middle Niger: Urbanism and the self-organizing landscape. Cambridge: Cambridge University Press.

Merlo, S. (2016). Making visible: Three-dimensional GIS in archaeological excavation. In BAR international series 2801. Oxford: British Archaeological Reports Oxford Ltd..

Monroe, J. C. (2014). The precolonial state in West Africa: Building power in Dahomey. Cambridge: Cambridge University Press.

Monroe, J. C., \& Ogundiran, A. (Eds.). (2012). Power and landscape in Atlantic West Africa: Archaeological perspectives. Cambridge: Cambridge University Press.

Olorunfemi, M. O., Ogunfolakan, B. A., \& Oni, A. G. (2019). Geophysical and archaeological survey in Igbo Oritaa (Iwo), Southwest Nigeria. African Archaeological Review, 36(4), 535-552.

Opitz, R., \& Cowley, D. (Eds.). (2013). Interpreting archaeological topography: Lasers, $3 D$ data, observation, visualisation and applications. Occasional publication of the aerial archaeology research group, no. 5. Oxford: Oxbow Books.

Opitz, R., \& Herrmann, J. (2018). Recent trends and long-standing problems in archaeological remote sensing. Journal of Computer Applications in Archaeology, 1(1), 19-41.

Osei, S. K. (2014). Combining geo-historical information with GIS techniques: An example of the historical slave route heritage in Ghana. In J. Anquandah, B. Kankpeyeng, \& W. Apoh (Eds.), Current perspectives in the archaeology of Ghana (pp. 65-88). Legon-Accra: Sub-Saharan Publishers.

Parcak, S. H. (2009). Satellite remote sensing for archaeology. London: Routledge.

Parcak, S. H. (2017). Moving from space-based to ground-based solutions in remote sensing for archaeological heritage: A case study from Egypt. Remote Sensing 8(12), 1297. https://doi.org/10.3390/rs9121297

Parcak, S., Gathings, D., Childs, C., Mumford, G., \& Cline, E. (2016). Satellite evidence of archaeological site looting in Egypt: 2002-2013. Antiquity, 90, 188-205.

Phillips, P., \& Willey, G. (1953). Method and theory in American archaeology: An operational basis for culture-historical integration. American Anthropologist, 55, 615-633.
Rayne, L., Bradbury, J., Mattingly, D., Philip, G., Bewley, R., \& Wilson, A. (2017). From above and on the ground: Geospatial methods for recording endangered archaeology in the Middle East and North Africa. Geosciences, 7, 100.

Reid, S. H. (2016). Satellite remote sensing of archaeological vegetation signatures in coastal West Africa. African Archaeological Review, 33(2), 163-182.

Richard, F. G. (2018). Reluctant landscapes: Historical anthropologies of political experience in Siin, Senegal. Chicago: University of Chicago Press.

Rüther, H., \& Rajan, R. (2007). Documenting African sites: The Aluka Project. Journal of the Society of Architectural Historians, 66(4), 437-443.

Rüther, H., Chazan, M., Schroeder, R., Neeser, R., Held, C., Walker, S. J., Matmon, A., \& Horwitz, L. K. (2019). Laser scanning for conservation and research of African cultural heritage sites: The case study of Wonderwerk Cave, South Africa. Journal of Archaeological Science, 36(9), 18471856.

Sadr, K. (2016). A comparison of accuracy and precision in remote sensing stone-walled structures with Google Earth, high resolution aerial photography and LiDAR: A case study from the South African Iron Age. Archaeological Prospection, 23(2), 95-104.

Sadr, K., \& Rodier, X. (2012). Google Earth, GIS and stonewalled structures in Southern Gauteng, South Africa. Journal of Archaeological Science, 39(4), 1034-1042.

Sampson, C. G. (1984). Site clusters in the Smithfield settlement pattern. The South African Archaeological Bulletin, 39, 5-23.

Sampson, C. G., Moore, V., Bousman, C. B., Stafford, B., Giordano, A., \& Willis, M. (2015). A GIS analysis of the Zeekoe Valley Stone Age archaeological record in South Africa. Journal of African Archaeology, 13(2), 167-185.

Schmid, T., Koch, M., DiBlasi, M., \& Hagos, M. (2008). Spatial and spectral analysis of soil surface properties for an archaeological area in Aksum, Ethiopia, applying high and medium resolution data. CATENA, 75(1), 93-101.

Schmidt, P. R., \& Pikirayi, I. (Eds.). (2016). Community archaeology and heritage in Africa: Decolonizing practice. New York: Routledge.

Seddon, J. D. (1968). An aerial survey of settlement and living patterns in the Transvaal Iron Age: Preliminary report. African Studies, 27(4), 189-194.

Sinclair, P. (1987). Space, time, and social formation: A territorial approach to the archaeology and anthropology of Zimbabwe and Mozambique c 0-1700 AD. Uppsala: Societas Archaeologica Upsaliensis.

Stahl, A. B. (1999). Perceiving variability in time and space: The evolutionary mapping of African societies. In S. K. McIntosh (Ed.), Beyond chiefdoms: Pathways to complexity in Africa (pp. 39-55). Cambridge: Cambridge University Press.

Thabeng, O. L., Adam, E., \& Merlo, S. (2019a). Spectral discrimination of archaeological sites previously occupied by farming communities using in situ hyperspectral data. Journal of Spectroscopy, Article ID 5158465.

Thabeng, O. L., Merlo, S., \& Adam, E. (2019b). High-resolution remote sensing and advanced classification techniques for the prospection of archaeological sites' markers: The case of dung deposits in the Shashi-Limpopo Confluence Area (Southern Africa). Journal of Archaeological Science, 102, 48-60. 
Welham, K., Fleisher, J., Cheetham, P., Manley, H., Steele, C., \& Wynne-Jones, S. (2014). Geophysical survey in sub-Saharan Africa: Magnetic and electromagnetic investigation of the UNESCO World Heritage Site of Songo Mnara, Tanzania. Archaeological Prospection, 21, 245-253.

Willey, G. R. (1953). Prehistoric settlement patterns in the Viru Valley, Peru. Bulletin 1. Washington: Bureau of American Ethnology.

Witten, A. (2006). Handbook of geophysics and archaeology. London: Equinox Publishing.
Wynne-Jones, S. (2012). Exploring the use of geophysical survey on the Swahili coast: Vumba Kuu, Kenya. Azania, 47(2), $137-152$.

Wynne-Jones, S., \& Fleisher, J. B. (Eds.). (2015). Theory in Africa, Africa in theory: Locating meaning in archaeology. London: Routledge.

Publisher's Note Springer Nature remains neutral with regard to jurisdictional claims in published maps and institutional affiliations. 